DOI https://doi.org/10.30525/978-9934-588-56-3.2.2

\title{
FIELD APPROACH TO PROFESSIONAL LEXICON STUDIES
}

\section{Naumchuk T. I.}

\section{INTRODUCTION}

Intensive development of science, technology and production that began in Europe in the $19^{\text {th }}$ century, led to the emergence of new realities that needed clear and unambiguous terms for their naming. Changes in the public consciousness and language in the context of society industrialization and the development of ethnic ties have made it necessary to study not only the languages but also their individual subsystems serving the professional needs. Certain social groups, united by common interests and professional activity, communicate through vocationally specific means, such as vocabulary units of the scientific and industrial fields, which generally form the relevant professional vocabularies.

The cinematic professional vocabulary is a lexical subsystem that consists not only of common vocabulary, but also of specific lexical units, such as terms, professional words, slang, jargon etc. Cinematograph is a unique sphere, vocabulary of which was formed on the basis of borrowed lexical units from scientific and professional vocabularies of other language subsystems. On the basis of the newly created vocabulary its further development began under the influence of the evolution of the cinematic sphere itself.

\section{The peculiarities of professional vocabulary}

The vocabulary of any industry develops according to the same trends as the common language itself, because it is a miniature, a certain "segment" that reflects general trends at its micro level. Language responds to changes in the surrounding world and is in endless interaction and development with it. The world is being enriched with new realities, objects, phenomena, and, accordingly, a new vocabulary emerges as a means of naming objects around the world, as the lexical level is the most dynamic and sensitive to linguistic and extralinguistic changes.

Scientists distinguish the following peculiarities of the lexicon:

- openness of the lexicon structure and high speed of updating its components;

- stylistic differentiation; 
- stylistic dynamism, which is manifested in the synthesis of styles with the use of colloquial and terminological vocabulary ${ }^{1}$.

In our opinion, the openness of the lexicon structure determines high speed of updating its components due to external influential factors (development of science and technology, dynamic social and political changes) and internal language needs, which are the desire to fill the lacunas in units' absence for the designation of one or another phenomenon, supplement its meaning, or differentiate it by stylistic or functional character.

Analyzing the tendencies of the professional vocabulary development, which is mostly made up of professional words, jargon and slang, it should be noted that their emotional and stylistic coloring is caused not by external factors, but the creative potential of the speakers. In an atmosphere of relaxed creative process, speakers are inclined to create new words and to "add" new meanings to existing linguistic units.

In support to this statement, it should be noted that one of the factors of language development $\mathrm{V}$. Levytskyi determines not only cognitive (development of thinking, cognitive activity, the need for nomination), but also emotional (which is the common human need to express their feelings) ${ }^{2}$. Therefore, the first sign of the lexicon implies the second one, which consists in stylistic differentiation of words (from emotionally neutral term to stylistically labeled jargon, professional words, etc.) and the third one, which consists in their coexistence and functioning within the same lexical system.

Cinematography is a field of activity that combines art and technical means of objectification. The artistic side is represented by the theater, which is based on the play of actors, the music accompanying the film and creating mood and specific atmosphere of the cinema. The technical component of cinema is represented by photo and cinema technologies that help shoot and demonstrate a feature.

The cinema lexicon is lexical units used by representatives of professional filmmaking groups, primarily actors, film directors, screenwriters, cameramen, and employees who serve all participants in the production process, film distribution and distribution agents. The vocabulary also includes lexical units of the viewers/fans language, who are also film process participants due to technologies that greatly empower modern

Чирвоний О.С. Комп'ютерний лексикон сучасної англійської мови: структурний, семантичний, функціональний аспекти : дис. ... канд. філол. наук : 10.02.04. Одеса, 2010. 276 с.

2 Левицкий В.Н. О внешних и внутренних факторах семантических изменений. Язык как развивающаяся реальная система. Диалектика развития языка. Москва, 1980. C. $159-161$. 
people. By its very nature, the language of the cinematographic sphere is capable not only of being one of the principal means of constructing reality, a repository of the vast variety of meanings, life experiences and possibilities of continuous objectification, but also of Meta culture and social communication of the XX - XXI centuries ${ }^{3}$.

Due to the status of cinema as a relatively new field of art, science and technology, in our study we can identify trends in the development of filmmakers since the emergence of this field, development over the past 150 years to the present stage of its history. Scientists identify three main models by which new branches of knowledge are formed:

- the first model - the emergence of new science on the basis of the already existing one;

- the second model - the formation of new science as a result of the interaction of two existing sciences;

- the third model is the emergence of new sciences as a result of the interaction of several sciences ${ }^{4}$.

The terminology of those sciences that were formed according to the first model is relatively homogeneous and consists of basic terms that are part of the source-system terminology, as well as their derivatives and complex terms. The terminology of the sciences, formed according to the second model is heterogeneous, since it is constituted by terms taken from related industries. The newly created terms are gaining new meanings under the influence of other related sciences. This complex nature of the underlying terms affects the value of derivatives and complex units within the term system. According to the principles of the third model, the kernel of the term system, which is part of the professional lexicon, acts as an integrating part of the terms from all interacting branches of knowledge. Its heterogeneity is that the basic terms completely change their original meaning, some are subject to modification, and others completely change their original value ${ }^{4}$.

In our opinion, the cinematographic industry was formed according to the second model i.e. based on the integration of the theatrical art with photo technology, and therefore, the English cinematic vocabulary was formed as a reflection of the interaction of scientific, technical and artistic concepts. Their theoretical and conceptual bases formed the basis for the newly created field of cinema.

3 Жигалкіна С.С. Кіно як засіб конструювання реальності (філософськокультурологічний аналіз) : автореф. дис. ... канд. філос. наук : 09.00.04. Сімферополь, 2010. 20 с.

Куделько З.Б. Англійська терміносистема ринкових відносин : синтагматичні та парадигматичні особливості : дис. ... канд. філол. наук : 10.02.04. Чернівці, 2003. $243 \mathrm{c}$. 


\section{Field approach basics}

One of the fundamental areas of theoretical understanding of language in understanding the principles of its structure is a systematic approach. The first scholars to substantiate the need to consider language as a systemic phenomenon were W. von Humboldt and F. de Saussure. The systematic character of the vocabulary was first investigated by M. Pokrovsky, who determined the connection of words within one circle of representations and O. Potebnya, who distinguished semantic relations between words within semantic groups and others.

J. Trier is considered to be the founder of the theory of systematic approach in the study of vocabulary. He developed and applied the new principles of systematic analysis of vocabulary. According to J. Trier, all words are related to a specific meaning and do not exist in isolation, but within the field. The scientist distinguished two types of fields: conceptual (the structure of a certain conceptual sphere) and verbal (a group of words that are related to each other in meaningful terms and determine the meaning of each other). Hence, linguists call these fields lexical-semantic because they combine the lexical units on a semantic basis.

The term "lexical-semantic field" (hereinafter LSF) is defined as a set of linguistic units united by a common (integral), lexical-semantic feature ${ }^{5}$, as existing realities that combine individual words and general groupings of words - vocabularies. A common semantic characteristic is usually expressed by a generic value lexeme and integrates all units of the field ${ }^{6}$.

There are two ways to determine the composition of $\left.\mathrm{LSF}^{7}: 1\right) \mathrm{LSF}$ is distinguished on the basis of the general concept expressed in the words of this field, where lexical units are classified according to the revealed areas of reality; 2) LSFs are distinguished on the basis of a particular word (or group of words); 3 ) in accordance with the distributive-statistical principle, LSFs can be distinguished on the basis of statistics on the compatible recurrence of words in the text, i.e. on their distribution. The more cases of co-occurrence of words, the more closely they are interconnected and can be combined into one LSF; 4) LSF can be distinguished based on associative experiment data obtained from a survey of native speakers. LSFs thus combine the most frequent response words.

${ }^{5}$ Ключка Н.Я. Лексико-семантичне поле як системно-структурне утворення. Наукові записки. Сер. : Філологічна. Острог, 2012. № 24. С. 129-131.

6 Лех О.С. Лексико-семантичне поле як структурний компонент та метод його дослідження. URL: http://www.rusnauka.com/DN2006/Philologia/3_leh\%20o.s.doc.htm.

7 Гольдберг В.Б. Контрастивный анализ лексико-семантических груп : (на материале английского, русского и немецкого языков). Тамбов : ТГПИ, 1988. $56 \mathrm{c}$. 
The first of the above mentioned approaches is the most relevant in the study of the cinematic lexicon, since its formation and development are based on common principles, and the "field" approach allows a clear definition of the structural organization of the vocabulary. The selection of semantic fields is based more on a logical, conceptual than on a linguistic criterion. In the semantic field words are of different parts of speech and they are related to a broad concept ${ }^{8}$. Semantic field also includes phraseological units and units of both literary and colloquial/slang vocabulary.

LSF is a broad concept that encompasses many interrelations within its system. The most important paradigmatic relations within LSF are hyperhyponomic (generic) relations that establish correlation between microfields and fields, that is, between units of different levels of logical abstraction. The integrative features of microfields are differentiated for fields of higher levels ${ }^{9}$.

Within one LSF, there are also lexico-semantic variants (hereinafter LSVs), which in the semantic aspect are considered as semantic components and relations between them. Component analysis allows identifying the integrating component by which words are combined in a field ${ }^{10}$.

Linguists I. Kobozeva ${ }^{11}$ and I. Chumak ${ }^{12}$ distinguish the following field properties:

- a semantic field formed by a large number of meanings with a common component (semantic feature), which is expressed by an arch lexeme (hyper lexeme), the lexeme with the most generalized value;

- the presence of semantic relations (correlations) between words, namely in their internal structure;

- micro fields are distinguished in the lexico-semantic field - they are semantic associations members of which are bound by an integral trait, which is usually expressed by the dominant of the micro field (kernel lexeme). The outer structure of the micro field is the kernel and several regions, some of which may be located in close proximity to the kernel (near periphery) and others at the periphery of the micro field (distal periphery);

${ }^{8}$ Павлишенко О.А. Квантитативні характеристики лексико-семантичних полів дієслова в авторських текстах англомовної художньої літератури : дис. ... канд. філол. наук : 10.02.04. Львів, 2017. $211 \mathrm{c.}$

${ }^{9}$ Васильев Л.М. Теория семантических полей. Вопросы языкознания. 1971. № 5. C. $105-113$.

10 Арнольд И.В. Лексико-семантическое поле в языке и тематическая сетка текста. Текст как объект комплексного анализа в ВУЗе. Ленинград, 1984. С. 3-11

11 Кобозева И.М. Лингвистическая семантика. Изд. 2-е, стер. Москва : Эдиториал УРСС, 2004. 352 с.

12 Чумак-Жунь И.И. Лексико-семантическое поле цвета в языке поэзии И.А. Бунина: состав и структура, функционирование : автореф. дис. ... д-ра филол. Наук : 10.02.01. Киев, 1996. 20 с. 
- interdependence of lexical units (the field is characterized by the interdependence of elements, that sometimes acts in the form of interchangeability of these elements);

- interrelation of semantic fields throughout the lexical system (LSFs are not isolated from each other. Each word enters a certain LSF and, due to its ambiguity, can move to another LSF);

- systematic and relative autonomy of the field;

- one semantic field may be included in another higher-level field (hierarchy).

Scientists designate the kernel of the system as the area with the highest probability of occurrence of a particular lexical unit. The factor of increased linguistic redundancy of special lexical units is defined by the industry terminology itself as a relatively closed autonomous lexical-semantic system. In the kernel zone, the desire for special lexical units to express a clear correspondence between the linguistic sign and the concept is most intense. Increased frequency, the pursuit of unambiguous compliance, welldefined system coordinates provide lexical-semantic reliability and stability of branch terminology, which allows it to act as an invariant (lexicalsemantic standard) when using the term in any other act of communication.

The field principle of organizing the language system indicates that there is a mandatory periphery in each field. No linguistic phenomenon can consist only of the kernel, since the periphery is as much a full-fledged element of the lexical system as the kernel ${ }^{13}$. Moreover, defining the lexical-semantic field as "a semantic-paradigmatic formation having a certain autonomy and specific features of organization: a common non-trivial part in interpretation, a kernelperipheral structure, the existence of zones of semantic transition"14, the latter provision emphasizes the openness and dynamism of the LSF.

The field functions are distributed between the kernel and the periphery: one part of the functions is assigned to the kernel and the other to the periphery. There is no clear boundary between the kernel and peripheral zones. The constituent elements of a field may belong to the kernel of one field and simultaneously be on the periphery of another field ${ }^{15}$. Therefore, the semantic structure of the field is composed of the following constituents:

\footnotetext{
${ }^{13}$ Стернин И.А. Проблемы анализа структуры значения слова. Воронеж : Изд-во Воронежского университета, 1979. $156 \mathrm{c}$.

14 Денисова С.П. Типологія категорїй лексичної семантики. Київ : Вид-во Київського держ. лінгвістично ун-ту, 1996. 294 с.

15 Гумовська I.M. Англійська юридична термінологія в економічних текстах: генезис, дериваційні та семантико-функціональні аспекти : автореф. дис. ... канд. філол. наук : 10.02.04. Львів, 2000. 19 с.
} 
- the kernel of the field, represented by the generic sem (hypersem). The field hypersem is a higher-order semantic component that organizes semantic field deployment around it;

- the center of the field, which consists of units with integral, differential value common to the kernel;

- the periphery of the field, which includes the units farthest from the kernel. Usually peripheral units of the field can come into contact with other semantic fields, forming a lexical-semantic continuity of the language system $^{12}$.

The lexicon, as an open dynamic hierarchical system, is also formed on the principle of kernel and periphery. There are the following criteria for kernel-peripheral LSF membership:

- words that form the kernel, as a rule, are simple in their morphological structure;

- kernel lexemes have wider combinability;

- kernel lexemes are more psychologically significant;

- borrowings usually refer to the periphery, not the center;

- the semantics of kernel words are generally wider than the semantics of peripheral lexemes ${ }^{16}$;

- peripheral sections have a zone division according to the degree of distance of their units from the kernel ${ }^{17}$.

The isolation of the kernel and central zones, as well as the near / far periphery, indicates the fuzzy boundaries of the kernel-peripheral structure, elements of which are in a state of constant migration i.e. transitions from one level to another. But such processes are more inherent in the periphery, and the kernel units are in a state of relative stability.

Proponents of the field approach to vocabulary systematization are of the opinion that word affiliation to the kernel or periphery of the field is relatively conditional, since the outer and inner boundaries of the lexical fields are rather blurred ${ }^{18}$. D. Geeraerts also notes that semantic fields are not clearly delimited internally and externally, like pieces of a mosaic. "The whole lexicon would then be a huge superfield that breaks down into large but clearly delimited parts, which in turn are divided into smaller field structures and so on until we reach the initial level of a single mosaic stone -

${ }^{16}$ Кузнецов А.М. Структурно-семантические параметры в лексике. Москва : Наука, 1980. $160 \mathrm{c}$.

Костенко Н.Д. Структурно-семантичні та функціональні параметри англомовних інновацій семантичного поля «Навчання» : дис. ... канд. філол. наук : 10.02.04. Запоріжжя, 2016. 309 с.

18 Близнюк К.Р. Системно-структурна організація семантичного мікрополя «poświęcenie» у польській мові. Магістеріум. 2017. Вип. 66 : Мовознавчі студії. C. 21-25. 
words $<\ldots>$ Discretion is usually manifested only in the kernel of the field around which a peripheral transition zone operates, the words being clearly defined will be difficult to identify" ${ }^{\prime 19}$.

We agree with the view of the researchers and believe that the semantic field cannot be clearly defined due to the dynamism inherent in language, in particular the lexical-semantic system. The lexeme belonging to the kernel can migrate to the periphery and vice versa. Within the English language lexicon of cinematography, we distinguish the near and far periphery according to the criterion of temporal marking of the lexical units that are part of them. Thus, neologisms that nominate modern realities and concepts constitute the near periphery, and the distant one is represented by historicisms that have gone beyond everyday usage due to the loss of relevance of the realities that have nominated corresponding lexemes.

This criterion allows monitoring the evolution of the vocabulary. Within the central periphery, the central area of the near periphery, formed by the professional words of the cinematographic sphere, as well as the remote area of the near periphery represented by slang words, should also be distinguished. This approach has a sociolinguistic character and reveals trends in the functioning of the branch of vocabulary units at the present stage.

As part of the lexicon under study it is possible to distinguish a "kernel term group", which includes special terms of the industry, a pivotal and related group of names, as well as their closest "co-names" (by analogy to semantic fields $)^{20}$. Consequently, the kernel of a movie lexicon is represented by basic terms that combine the names of cinema system's basic concepts. In addition, within the kernel of the cinema lexicon it is expedient to distinguish the lexemes that form the center of the kernel site and represent generic names of derivatives by the value of kernel units. Therefore, the kernel of the English lexicon of the cinematic sphere is the lexemes that belong to the literary language: cinema, actor, producing, lighting, camera, assembling, sound-editing, genre, distribution, projector, play. They name the basic concepts of cinematic sphere and form the basis of English-language cinematic vocabulary.

Kernel lexicon includes professional terms derived from central units such as film actor, leading actor, animated film, cartoon, assistant director, associate producer, background illumination, booster light, camera angle, close up, production costs, distribution rights, fairy-tale movie, key scene,

${ }^{19}$ Geeraerts D. Theories of lexical semantics. New York : Oxford University Press Inc., 2010. 362 p.

${ }^{20}$ Верста I.М. Про ядро соціолінгвістичної термінології. Наукові праці. Сер. : Філологічні науки. 2007. Т. 67, вип. 54. С. 18-21. 
bloomed lens, claw, color rendition, concave, lenticular screen, dissolve, duping process, gantries, gyro-tripod, plunger, take-up spool etc. A clear understanding of the meaning of such words is limited by the basic technical knowledge of a particular profession and needs clarification.

The near periphery, in turn, is formed by professional words stylistically-colored lexical units, which belong to the vocabulary of limited professional groups and are the colloquial equivalents of special terms. Professional words of the cinema lexicon are the following words: daddy, long ear, watchdog, props, filler, gelatin. These units function in the everyday communication of working groups of cinematographers as the colloquial equivalents of professional terms and reflect in their meaning both positive and negative connotations.

The periphery is also represented by a stylistically-colored vocabulary that is jargon and slang: brifie, chinema, pickcrick, cinemantics, actorvist, CGI fatigue, hate-watch, cinema, breakdown, reelboy etc. The meaning perception of the lexemes of this group is complicated by their belonging not only to the professional lexicon, but also to the vocabulary of closed social groups with the obligatory connotation-marked element of meaning. It should be noted that such units usually function as neologisms and therefore reflect the current realities of public/professional life. The film industry itself is known to be a social phenomenon that reflects the essence of the synergy of the creative process, intellectual and physical labor, and its product is a piece of art.

The distal periphery is formed by lexical units that went beyond the common usage and ceased to reflect the realities of modern / current life. Such units include historical words: silenced studio camera, caption, kinetoscope, film bin, gelatin, blinkies, pic factory. It should be noted that the lexicon of the cinema industry is characterized by historic words, not archaic ones. This phenomenon is caused by the rapid processes of archiving the vocabulary in connection with the rapid development of modern technologies, which causes obsolete vocabulary beyond the boundaries of communicative functioning due to the disappearance of the reality of its designation. That is, the vocabulary "does not survive" to the status of archaic word, and is replaced in the lexicon by neologism to indicate a new reality.

Thus, language, as a verbal means of objectifying reality, reflects in its content and structure certain processes and their characteristics. Kernel lexical units for the designation of technology have a specific and laconic semantic load, devoid of connotations, unlike stylistically colored units of the peripheral lexical layer. It is in the lexical-semantic and stylistic peculiarities of the units of each structure that there is a certain remoteness of the periphery from the kernel. 


\section{Terms as kernel elements}

Linguistic studies of various specialized fields' terminology, as well as the practice of compiling professional vocabularies indicate that the terminology of any field includes:

- general scientific vocabulary, which forms the general fund of the terminological system of scientific and technical functional style as a whole;

- a special vocabulary that makes up the subsystem of terms in this field $^{21}$. In addition, scientists note that the phenomenon of inter-system borrowing of lexemes within a certain terminological field is quite common, which is a productive way of forming modern term systems ${ }^{22}$.

Thus, we can conclude that the term denotes and nominates a certain concept of the professional industry and is an integral part of the term system, which is formed by the creation and interaction of industry concepts (terms). The main features of the term system are integrity, stability and structure. Undoubtedly, the language of a particular industry is formed on the basis of artistic (literary), since it cannot exist in isolation. Its characteristic feature is the presence of a term system, the kernel of its lexicon. As it has already been mentioned, each linguistic system can be represented by the model of the kernel-peripheral structure, and thus the subtext of a particular branch, the difference of which is determined precisely at the lexical level, can be represented in the form of a field with its kernel and periphery.

The cinematographic industry's terminology was formed on the basis of existing systems, such spheres of the English-speaking society, as theater and photography, and is the result of the integration of both spheres. Cinema is an actor's play shot by photographic devices. Therefore, the kernel of the cinema system is formed by units of the above systems. We have found such commonalities for theatre and cinema branches as actor (film actor, playactor), key-actor, actress, director, producer, stage manager, assistant director, costume designer, set decorator, extra, prompter, boom operator, property master, on set dresser, usherette etc. These lexical units denote professions that are common to both theater and cinema. In this case, during the migration of elements from one term system to another, the meaning of the words has remained unchanged, indicating the close connection of the two conceptual spheres.

Another common thematic group of theater and cinema is acting. The very notion of acting has remained unchanged, and therefore the lexemes,

21 Кузнєцова І.В. Семантичні процеси формування термінологічних систем. Нова філологія. 2010. № 42. С. 107-112.

22 Грицьків А.В. Міжсистемна взаємодія як чинник термінотворення (на прикладі англомовних фінансових термінів) : дис.... канд. філол. наук : 10.02.04. Тернопіль, 2004. 256 с. 
which denote expressive means, were transformed into the terminology of the cinema industry without significant semantic modifications. This phenomenon is illustrated by examples such as acting, part, role, artist, guest actor, comedian, villain, misact -"inappropriate role", gag - "comic show", ham - "bad acting", fluff - "poorly understood role". "Giving a performance" and "presenting a movie" are denoted by present, render, and the word debut means "acting debut", the phrase heyday of fame is "the pinnacle of acting glory". Cinematic and theatric dramas both have scripts. Derivatives of this lexeme are filmscript, shooting script, movie script, expressed in complex words and phrases.

No less important area that influenced the formation of the film industry is photography. The results of the study, obtained during the analysis of lexicographic sources, revealed the fact that the elements of the photo industry make up a large part of the lexicon of cinema. These units generally reflect the process of making a film from a technical point of view. The following nominative units were also borrowed from the field of photography: lens, mask, viewfinder eyepiece, handgrip, eyecup, zooming lever, etc. These units are common to the field of cinema and photography, as they operate within a single terminology. Therefore, the meanings of these words remain unchanged.

To that list we can also add motion, art of lightning, assembling, background - "background of the scene being shot". It should be noted that this unit moved from the field of general use to a number of terminological units by semantic derivation, and was transferred from the field of photography to the field of cinema, which clearly illustrates the process of transterminologization. These also include: film bin, can, develop, juxtaposition, film projector, which is derived from the lexeme "projector". The technical equipment of the cinematographic process is illustrated by such units as rectifier, film break detector, film path, reel (film), feed, lamphouse, photocell, mobile cinema, viewfinder camera.

The kernel of the terminology system can also include such special lexemes as boom, booth, stage box, camera etc. Derived from the latter is cameraman. During the filming, special professional cameras were used: motion picture camera, film camera, high-speed camera, newsreel camera, soundproof motion picture camera, professional narrow-gauge motion camera $=16 \mathrm{~mm}$ camera. Cameras were improved, more complex elements were added, which allowed to improve the image.

According to the results of terminology analysis at the conceptual level, a thematic classification was carried out, which made it possible to combine terms into thematic groups. The kernel of cinematic terminological system was formed as a result of borrowing units from the fields of theater and 
photography. In the process of transterminologization of borrowed lexical units, they have undergone a narrowing or specialization of meaning.

With the development of the film industry, the kernel of its lexicon has been enriched with terms from such areas as acoustics (sound producer, dubbing, orchestration, blimp, boxing, AB roll, double play, buzz track, voice processing, foley artist, sound recording, sound mixing, acoustic panel, amplifier, special effects equipment), optics (ambient light, bounce board, lighting man, art of lighting, lighting booth, lighting designer, gobo, optical sound recorder etc.), manufacturing (film industry, studio production, processing, technical direction, technology coordinator, $I X$ engineers, post-production, supervisor, line producer, stage-hand), business/distribution (payrole accountant, trade mark, block-booking, distribution, commercial venture, show bizz, tie-in, clearance), advertising (promotion, campaign, publicity photographs, pressbooks, trailer, logline etc.), multimedia technologies (digital cinema, animated graphics, computer desktop film production, cyberthriller, machine cinema, smart cartoon, computer graphics imagery (CGI), color cycling, high resolution (hi-res), pixillation), and others.

\section{Periphery elements}

Peripheral constituents of the professional vocabulary are such variants of nominative units as professional words, slang, jargon, etc. Each such unit correlates with the terminological constituents of the kernel, but depending on the degree of its semantic affinity can be remote, or, conversely, close to the center (kernel). In modern linguistics there is a problem of differentiation of professional words and jargon, as both versions of the sociolect belong to the lexicon of the professional field, as well as the identification of the semantic load of units of jargon and slang through their stylistic labeling.

In our opinion, professional words perform the function of an accurate, often expressive colloquial equivalent of the terms of the subsystem under analysis. For example, within the English lexicon of cinematic industry, the following professional words can be distinguished: the assistant director is jokingly called daddy, a sound engineer, better known in narrow professional circles as a long ear - they must have "long ears" in accordance with their responsibilities. The film censor, whom everyone knows as censcissors, must carefully and honestly review and control all the material like a watchdog before cutting the film with his "scissors".

The person in charge of props at the film studio has the same name props, and the film journalist is jokingly called a fan magger. The professional word of filler means "a short film that complements the program of the screening", gelatin - the "film" itself, and the verb of general literary language to exaggerate acquires a narrow professional semantics and 
is interpreted in the professional language of cinematographers as "play a role" with deliberate exaggeration.

Jargons are words the use of which is limited by the norms of communication adopted in a particular social environment. Jargons are mainly such specific, emotionally colored names of concepts and objects that have normative equivalents in literary language and, deviating from it, give the process of communication an atmosphere of ease, irony, familiarity, $\operatorname{etc}^{23}$.. Jargon as a social and linguistic phenomenon generates not only new nominations, but also bright, figurative words. The main stylistic peculiarity of slang vocabulary semantics is metaphorical quality and reinterpretation of words in the literary language. The meaning of these words is motivated and based on certain associations.

For example, we single out such jargon words as cackle, which means "babbling" in the general literary language, whereas within the cinematic lexicon it means "dialogue". The lexeme brifie, the direct meaning of which in associations resembles something "short". From the dictionary definition of "short summary of the case" follows the meaning of the lexical unit "short film". According to a similar associative model, the jargon quicky (derived from the adjective quick - "fast, hasty"), means "low-budget film made in a hurry".

Slang is a sociolect that originated from the Argo of various closed social groups, emotionally colored vocabulary of low and familiar style, common among the lower classes and certain age groups. The American writer Carl Sandburg describes slang as "a language that rolls up its sleeves, spits on its hands and goes to work" 24 . Often the word "slang" is used simply as a synonym for the word "jargon". But in our study we distinguish between these concepts. We support the idea that the sphere of slang usage is broader than that of jargon, as it can exist among different groups of speakers regardless of social status, professional orientation, age restrictions, etc., in contrast to the jargon that operates within professional groups. We agree that it is impossible to establish clear stylistic boundaries in the difference between jargon and slang, as language is an open and dynamic system that constantly updates its resources through incessant processes of interaction between its elements, which causes variations of language units as semantic, and on stylistic levels.

Therefore, we can observe such phenomena when a lexical unit is formed within closed professional groups, i.e. functions in the form of jargon, but later, spreading in the general language, loses its "professional affiliation"

${ }^{23}$ Жаргон. Украӥнська мова : енциклопедія. Київ, 2000. С. 167.

${ }^{24}$ McQuain J. Homegrown English: How Americans invented themselves and their language. New York : Random House, 1999. 278 p. 
and becomes a slang unit. In this case, in our opinion, to determine the status of the lexeme, we must take into account the sociolinguistic conditions of its occurrence, which will trace the evolution of its semantic and stylistic features. We can find confirmation of that in examples where the slang units of the film industry were formed within a professional circle, functioned as jargon, but later became commonly used. These include lexemes barkies, brifie, quicky, flicker, macaroni and others. The jargon barkies means "sound film" and was formed on the basis of the associative series of the word bark - "make loud sounds". According to the similar model jargon word blinkies - "film" was formed, the meaning of which is based on the lexeme "blink". The film was jokingly called gelatin because it was made of a gelatinous material, and, having a considerable length, "turned" into macaroni, spaghetti. Cinema fans are called movie nut because they "snap" all the novelties of the cinema world like nuts, and a performer who loves comics and "ad-lib" is known as a gagster.

Having studied the evolution of the English lexicon of the cinematographic sphere, we have established that a certain number of the lexicon's constituents historic words denoting concepts that have disappeared in the process of historical development due to the loss of relevance of the referents they used to denote. Linguists call historicisms "temporally marked vocabulary" $"$. Historicisms are carriers of information about the temporal labeling of the word, denoting objects and phenomena that are characteristic of certain past eras. In addition, they can indicate the territorial affiliation of the word. Their lexical meaning has no emotional, evaluative, expressive components that express the speaker's attitude to reality $^{26}$.

Cinema developed very rapidly and dynamically precisely due to technical progress and social phenomena: the old technology was replaced by the new one, and the words denoting it passed out of speakers' use for the loss of relevance. Mass interest in cinema, which, on the one hand, reflected the realities of the time, and on the other hand, created a new reality on the screen, led to its active development. Thus new genres arose, as well as the principles of filmmaking, musical accompaniment, and later - the whole industry, which took a dominant position of cinema paradigm in the field of leisure and entertainment.

25 Некрасова Л.С. Функционирование историзмов в современном английском языке : автореф. дис. ... канд. филол. наук : 10.02.04. Санкт-Петербург., 2008. 23 с.

${ }^{26}$ Меняйло В.В., Кравченко С.В., Кузнецова Е.О. Классификация историзмов английского языка с целью интенсификации чтения аутентичных текстов исторической тематики. Вестник Санкт-Петербургского университета. Сер. : Филология, востоковедение, журналистика. 2015. № 1. С. 93-98. 
All phenomena were instantly reflected in the language, which recorded the emergence of both new lexical units (neologisms) and obsolete ones. For example, historic words with the word-forming component silent have lost their relevance at the present stage, but function within the lexicon of the corresponding historical period of silent cinema. Historic words also include nominatives such as film bin, can and nickelodeons - the type of first cinemas with a five-cent entrance fee.

Large reels of film have gone to history; they have been replaced by a "virtual film", which does not require the usual storage conditions. Obsolete are such technical devices as kinetograph, kinetoscope, bioscope. Such ways of filming as back projection, day-for-night shot, the reality of silent cinema called "American night", which meant "shooting night scenes in daylight" are gone, and new methods replaced them (bluescreen/greenscreen processing - "a type of processing using a blue/green background that serves as a stage for actors"). Accordingly, if realities disappear, the words that denote them lose their communicative relevance.

\section{CONCLUSIONS}

English professional cinematic lexicon is a kind (subclass) of common language lexicon that serves this field of knowledge, consists of an array of common language words, terms that define the specifics of this area, as well as stylistically marked units - professional words, jargon and slang.

One of the principles of researching lexical structure of language is the field principle of organization which allows allocating its kernel-peripheral structure. The English lexicon of the cinematographic sphere is a hierarchical formation that structures knowledge through logical relations between lexical units, within which paradigmatic connections are realized according to the principle of the semantic field, which consists in combining lexemes on a kernel integral basis. Accordingly, the entire lexicon in the form of LSF is formed on the kernel-peripheral principle.

The analysis of the material showed that the kernel of the terminological system of cinema is widely represented by units from the lexicon of theater and photography, which formed the basis of the cinema vocabulary during its formation. With the development of the cinema vocabulary, the kernel of the industry lexicon has been enriched with terms from such spheres as acoustics, optics, manufacturing, business (economics), multimedia technologies (computer technology, Internet), advertising, etc.

As part of the English cinema lexicon, we have singled out the kernel zone, which includes special terms of this field. The kernel center of the English cinema lexicon are lexical units that have lost their terminological status and now belong to the general literary language, for example: cinema, actor, producing, lighting, camera, assembling, sound-editing, genre, 
distribution, projector, play etc. These words name the basic concepts of the cinematographic sphere and form the basis of the cinema lexicon. Kernel lexical units, represented by professional terms, have a specific and laconic semantic load, devoid of connotations, in contrast to the stylistically colored units of the peripheral lexical layer. The far periphery is contrasted to the near one by the temporal marker that stands for frequency of lexical units' usage and illustrates the process of their archaization that is represented by historic words. They are the lexical-semantic and stylistic peculiarities of the field constitutives that determine their proximity / distance from the kernel of the branch vocabulary.

\section{SUMMARY}

The article deals with the field approach to professional lexicon studies based on the cinematic vocabulary. Field principle of vocabulary organization has allowed identifying its kernel-peripheral structure. It has been stated that kernel zone includes special terms of cinematography field. The terminological system of cinema is widely represented by units from the lexicons of theater and photography. Later it was enriched with terms from such spheres as acoustics, optics, manufacturing, business (economics), multimedia technologies (computer technology, Internet), advertising, etc. Peripheral lexical layer consists mainly of stylistically colored units, sociolects, e.g. slang, jargon, professional words. The proximity / distance from the kernel is determined by lexicalsemantic and stylistic peculiarities of the field constitutives.

\section{REFERENCES}

1. Чирвоний О.С. Комп'ютерний лексикон сучасної англійської мови: структурний, семантичний, функціональний аспекти : дис. ... канд. філол. наук : 10.02.04. Одеса, 2010. 276 с.

2. Левицкий В.Н. О внешних и внутренних факторах семантических изменений. Язык как развивающаяся реальная система. Диалектика развития языка. Москва, 1980. С. 159-161.

3. Жигалкіна С.С. Кіно як засіб конструювання реальності (філософсько-культурологічний аналіз) : автореф. дис. ... канд. філос. наук : 09.00.04. Сімферополь, 2010. 20 с.

4. Куделько 3.Б. Англійська терміносистема ринкових відносин : синтагматичні та парадигматичні особливості : дис. ... канд. філол. наук : 10.02.04. Чернівці, 2003. 243 с.

5. Ключка Н.Я. Лексико-семантичне поле як системно-структурне утворення. Наукові записки. Сер. : Філологічна. 2012. № 24. С. 129-131.

6. Лех О.С. Лексико-семантичне поле як структурний компонент та метод його дослідження. URL: http://www.rusnauka.com/DN2006/ Philologia/3_leh\%20o.s.doc.htm. 
7. Гольдберг В.Б. Контрастивный анализ лексико-семантических групп : (на материале английского, русского и немецкого языков). Тамбов : ТГПИ, 1988. $56 \mathrm{c}$.

8. Павлишенко О.А. Квантитативні характеристики лексикосемантичних полів дієслова в авторських текстах англомовної художньої літератури : дис. ... канд. філол. наук : 10.02.04. Львів, 2017. $211 \mathrm{c}$.

9. Васильев Л.М. Теория семантических полей. Bonpocbl языкознания. 1971. № 5. С. 105-113.

10. Арнольд И.В. Лексико-семантическое поле в языке и тематическая сетка текста. Текст как объект комплексного анализа в ВУЗе. Ленинград, 1984.

11. Кобозева И.М. Лингвистическая семантика. Изд. 2-е, стер. Москва : Эдиториал УРСС, 2004. 352 с.

12. Чумак-Жунь И.И. Лексико-семантическое поле цвета в языке поэзии И.А. Бунина: состав и структура, функционирование : автореф. дис. ... д-ра филол. наук : 10.02.01. Киев, 1996. 20 с.

13. Стернин И.А. Проблемы анализа структуры значения слова. Воронеж : Изд-во Воронежского университета, 1979. 156 с.

14. Денисова С.П. Типологія категорій лексичної семантики. Київ : Вид-во Київського держ. лінгвістичного ун-ту, 1996. 294 с.

15. Гумовська I.M. Англійська юридична термінологія в економічних текстах: генезис, дериваційні та семантико-функціональні аспекти : автореф. дис. ... канд. філол. наук : 10.02.04. Львів, 2000. 19 с.

16. Кузнецов А.М. Структурно-семантические параметры в лексике. Москва : Наука, 1980. 160 с.

17. Костенко Н.Д. Структурно-семантичні та функціональні параметри англомовних інновацій семантичного поля «Навчання»: дис. ... канд. філол. наук : 10.02.04. Запоріжжя, 2016. 309 с.

18. Близнюк К.Р. Системно-структурна організація семантичного мікрополя «ров́więcenie» у польській мові. Mazicmepiyм. 2017. Вип. 66 : Мовознавчі студії. С. 21-25.

19. Geeraerts D. Theories of lexical semantics. New York : Oxford University Press Inc., 2010. 362 p.

20. Верста I.М. Про ядро соціолінгвістичної термінології. Наукові nращі. Сер. : Філологічні науки. 2007. Т. 67, вип. 54. С. 18-21.

21. Кузнєцова I.В. Семантичні процеси формування термінологічних систем. Нова філологія. 2010. № 42. С. 107-112.

22. Грицьків А.В. Міжсистемна взаємодія як чинник термінотворення (на прикладі англомовних фінансових термінів) : дис. ... канд. філол. наук : 10.02.04. Тернопіль, 2004. 256 с.

23. Жаргон. Украӥнська мова : енциклопедія. Київ, 2000. С. 167. 
24. McQuain J. Homegrown English: How Americans invented themselves and their language. New York : Random House, 1999. 278 p.

25. Некрасова Л.С. Функционирование историзмов в современном английском языке : автореф. дис. канд. филол. наук : 10.02.04. СанктПетербург, 2008. 23 с.

26. Меняйло В.В., Кравченко С.В., Кузнецова Е.О. Классификация историзмов английского языка с целью интенсификации чтения аутентичных текстов исторической тематики. Вестник СанктПетербургского университета. Сер. : Филология, востоковедение, журналистика. 2015. № 1. С. 93-98.

\section{Information about the author:}

Naumchuk T. I.,

Candidate of Philological Sciences, Associate Professor at the Department of Foreign Languages

for Professional Communication National University "Zaporizhzhia Polytechnic" 64, Zhukovskoho str., Zaporizhzhia 69063, Ukraine 